\title{
Peningkatan derajat kesehatan masyarakat Bagan Sinembah melalui pengelolaan sampah rumah tangga menjadi barang bernilai ekonomi
}

\author{
Huriatul Masdar ${ }^{(1 * 1}$, Fifia Chandra ${ }^{2}$, Arfianti ${ }^{3}$, dan Yulia Irvani Dewi ${ }^{4}$ \\ ${ }^{1} \mathrm{KJF}$ Histologi, Fakultas Kedokteran, Universitas Riau \\ ${ }^{2}$ KJF Ilmu Kesehatan Masyarakat, Fakultas Kedokteran, Universitas Riau \\ ${ }^{3}$ KJF Biologi Kedokteran, Fakultas Kedokteran, Universitas Riau \\ ${ }^{4}$ Fakultas Keperawatan, Universitas Riau \\ * huriatul.masdar@gmail.com
}

\begin{abstract}
Abstrak. Sampah rumah tangga bila tidak dikelola dengan baik dapat menimbulkan berbagai masalah kesehatan. Pengelolaan sampah rumah tangga yang baik dapat bernilai ekonomis dan meningkatkan perekonomian masyarakat. Sampah organik dapat diolah menjadi kompos yang berguna bagi lahan pertanian sedangkan sampah non organik dapat didaur ulang menjadi barang-barang bernilai jual tinggi. Permasalahan pengelolaan sampah ini juga terjadi di Kecamatan Bagan Sinembah Kabupaten Rokan Hilir. Melalui kegiatan pengabdian kepada masyarakat Universitas Riau, dilakukan sosialisasi pengelolaan sampah organik dan anorganik serta pelatihan pembuatan kompos dan aplikasi seni decoupage pada barang bekas di rumah tangga. Tingkat keberhasilan kegiatan ini dinilai baik secara kualitas, namun masih kurang secara kuantitas peserta pelatihan. Peningkatan jumlah masyarakat sasaran perlu dilakukan agar upaya pengelolaan sampah di Bagan Sinembah menjadi lebih optimal.
\end{abstract}

Kata kunci: sampah rumah tangga; organik; anorganik; kompos; decoupage

Abstract. Household waste if not managed properly can cause various health problems. Good management of household waste can have economic value and improve the economy of community. Organic waste can be processed into compost that is useful for agricultural land while non-organic waste can be recycled into high-value items. This waste management problem also occurred in Bagan Sinembah Subdistrict, Rokan Hilir Regency. Through community service activities at University of Riau, socialization of organic and non-organic waste management, composting training and decoupage art applications on used goods in households were conducted. The level of success of this activity is considered good in quality, but the quantity of trainees is still lacking. Increasing the number of target communities needs to be done so that the waste management efforts at Bagan Sinembah become more optimal.

Keywords: household waste; organic; non-organic; compost; decoupage

To cite this article: Masdar, H., F. Chandra, Arfianti, \& Y. I. Dewi. 2019. Peningkatan derajat kesehatan masyarakat Bagan Sinembah melalui pengelolaan sampah rumah tangga menjadi barang bernilai ekonomi. Unri Conference Series: Community Engagement 1: 158-162. https://doi.org/10.31258/unricsce.1.158-162

Peer-review under responsibility of the organizing committee of Seminar Nasional Pemberdayaan Masyarakat 2019 


\section{PENDAHULUAN}

Kesehatan lingkungan merupakan salah satu faktor yang memegang peranan penting terhadap terjaminnya kualitas kesehatan manusia. Ruang lingkup kesehatan lingkungan antara lain mencakup perumahan, pembuangan kotoran manusia (tinja), penyediaan air bersih, pengelolaan sampah, pembuangan air limbah, rumah hewan ternakdan sebagainya. Sampah rumah tangga seringkali menjadi sumber masalah kesehatan apabila tidak dikelola dengan baik. Sampah rumah tangga yang menumpuk menjadi tempat hidup berbagai vektor penularan penyakit infeksi, bahkan dalam jumlah besar dapat mencemari sumber air bersih yang digunakan oleh masyarakat sehari-hari (Chandra, 2007).

Secara umum, sampah dikategorikan atas sampah organik yang bisa terurai ditanah dan sampah non organik. Sampah non organik juga menimbulkan masalah tersendiri. Sifat bahannya yang tidak bisa diurai oleh mikroba yang ada ditanah menyebabkan sampah ini akan terus bertahan hingga bertahun-tahun dalam bentuk aslinya. Wadah-wadah bekas yang terbuat dari plastik, seperti gelas atau plastik bekas air mineral, botol kaca, kaleng bekas, pot bunga yang tidak terpakai dan lain sebagainya, bila dibiarkan begitu saja ditempat pembuangan sampah akan dapat menampung air saat turun hujan dan menjadi tempat perindukan nyamuk demam berdarah (Faizah, 2008).

Sejalan dengan amanat Undang-Undang nomor 32 tahun 2004 dan Peraturan Pemerintah nomor 38 tahun 2007, masalah sanitasi merupakan salah satu program wajib yang harus dijalankan oleh pemerintah kota/kabupaten, termasuk di Kabupaten Rokan Hilir. Di Kabupaten Rokan Hilir, sampah masih menjadi masalah yang harus diatasi oleh pemerintah, baik yang berasal dari daerah industri, perkantoran maupun rumah tangga.

Kabupaten Rokan Hilir merupakan salah satu dari 4 kabupaten di Provinsi Riau yang berkewajiban melaksanakan percepatan pembangunan sanitasi dan pemukiman mulai tahun 2015 berdasarkan amanat Keputusan Mentri Dalam Negeri Republik Indonesia nomor 648-82/Kep/Bangda/20115. Selain itu, hasil survei petugas Puskesmas yang tertuang dalam Profil Kesehatan Kabupaten Rokan Hilir tahun 2015, terlihat adanya penurunan jumlah rumah tangga yang ber-Perilaku Hidup Bersih dan Sehat menurun drastis dari 66,29\% pada tahun 2010 menjadi 35,4\% pada tahun 2013 dan mulai meningkat kembali menjadi 53,5\% pada tahun 2014. Indikator yang dinilai dalam PHBS ini termasuk diantaranya pemberantasan jentik nyamuk, penggunaan air bersih dan pengelolaan sampah di rumah tangga (Dinkes Rohil, 2015).

Bagan Sinembah merupakan salah satu dari 14 kecamatan yang terdapat di Kabupaten Rokan Hilir. Kecamatan ini memiliki luas wilayah 141.225 Ha dengan luas wilayah terbangun 733,05,44 Ha, jumlah penduduk 141.794 jiwa dengan kepadatan 42 jiwa/Ha. Meskipun, berdasarkan data Dinas Kesehatan 2015, Kecamatan Bagan Sinembah termasuk Kecamatan dengan capaian PHBS diatas rencana strategis, namun beberapa wilayah Kecamatan Bagan Sinembah ini dinilai beresiko terhadap pencemaran sampah, salah satunya Desa Pelita dan Sukamaju merupakan desa yang beresiko tinggi terhadap pencemaran sampah. Disamping itu, sampah rumah tangga yang terangkut oleh petugas Dinas Kebersihan hanya 5,4\% dari total sampah rumah tangga yang dihasilkan, sisanya dibakar, dibuang ke dalam lubang namun tidak ditimbun dengan tanah, atau ditumpuk begitu saja hingga membusuk. Praktik pemilahan sampah organik dan non organik di rumah tangga pun masih sangat rendah, dimana hanya 14,3\% rumah tangga yang melakukan pemilahan sampah. Beberapa permasalahan lain seperti jumlah TPS yang tersedia dan mobil pengangkut sampah yang belum memenuhi kapasitas juga menjadi penyebab terjadinya tumpukan sampah di Kecamatan Bagan Sinembah (Dinkes Rohil, 2015).

Sampah rumah tangga apabila di kelola dengan baik, selain dapat melindungi keluarga dari penularan penyakit, juga dapat bernilai ekonomi. Sampah organik bisa dijadikan kompos, dimana kompos memiliki banyak keuntungan, baik dari aspek kesehatan lingkungan maupun ekonomi. Keuntungan dari aspek kesehatan lingkungan meliputi mengurangi polusi udara karena pengelolaan sampah dan limbah dengan cara dibakar akan mencemari udara lingkungan, mengurangi polusi udara karena pelepasan gas metana dari sampah organik yang membusuk akibat bakteri metanogen di tempat pembuangan sampah, mengurangi faktor resiko munculnya penyakit akibat sampah. Sedangkan dari aspek ekonomi, keuntungan membuat kompos antara lain adalah menghemat biaya untuk pengangkutan dan penimbunan limbah, mengurangi volume atau ukuran limbah, memiliki nilai jual yang lebih tinggi dari bahan asalnya, dan menghemat biaya untuk membeli pupuk tanaman (Damanhuri E, 2010). Sementara itu, sampah non organik bisa diolah menjadi berbagai kerajinan tangan yang akan memiliki nilai jual lebih tinggi ketimbang hanya dijual ke pengepul barang bekas.

Oleh karena itu, perlu diadakan rangkaian kegiatan untuk mengoptimalkan peran serta masyarakat dalam pengelolaan sampah rumah tangga mulai dari pemilahan sampah organik dan non organik hingga pengolahan 
sampah tersebut menjadi barang yang bernilai ekonomi, salah satunya dengan menggunakan teknik decoupage. Kegiatan ini akan dilaksanakan bersama mahasiswa Kukerta Universitas Riau yang ditempatkan di Kecamatan Bagan Sinembah.

\section{METODE PENERAPAN}

Kegiatan ini dilaksanakan dengan melibatkan mahasiswa Kuliah Kerja Nyata (KKN) Universitas Riau yang ditempatkan di Kepenghuluan Pelita Sukamaju dan Kepenghuluan Sukamaju Kecamatan Bagan Sinembah. Adapun tahap-tahap kegiatan yang dilaksanakan sebagai berikut:

\section{Tahap Persiapan}

Pada tahap ini, tim melakukan koordinasi dengan mahasiswa Kukerta di Kepenghuluan Pelita dan Kepenghuluan Sukamaju untuk perencanaan pelaksanaan kegiatan yang dilanjutkan dengan survei lokasi kegiatan untuk mengetahui karakteristik masyarakat target serta berdiskusi dengan aparat pemerintah setempat. Dari hasil observasi dan diskusi tersebut didapatkan dua kelompok masyarakat yang cukup aktif dan dinilai mampu menjadi penggerak dalam sosialisasi kegiatan pengolahan sampah rumah tangga ini nantinya. Dua kelompok masyarakat ini adalah guru dan ibu-ibu PKK di kedua kepenghuluan tersebut.

\section{Tahap Sosialisasi Kegiatan}

Pada tahap ini mahasiswa Kukerta menyosialisasikan rencana kegiatan ke masyarakat target di kedua kepenghuluan tersebut.

\section{Tahap Pelaksanaan}

1. Sosialisasi tentang pengelolaan sampah rumah tangga, mulai dari pemilahan sehingga cara pemusnahan sampah rumah tangga yang benar apabila tidak akan didaur ulang. Kegiatan ini dalam bentuk seminar dengan melibatkan aparat pemerintahan setempat.

2. Pelatihan pembuatan kompos dari sampah organik di rumah tangga. Selain pelatihan pembuatan kompos, akan dikenalkan juga berbagai tanaman berkhasiat obat yang nantinya dapat ditanam oleh masyarakat di pekarangan masing-masing. Dengan demikian, kompos yang dihasilkan, selain dapat digunakan untuk pertanian yang sudah ada, bisa juga digunakan sebagai pupuk tanaman berkhasiat obat tersebut, serta juga dapat dijual ke petani di daerah sekitar.

3. Pelatihan Decoupage Art dengan memanfaatkan sampah non-organik rumah tangga seperti botol kaca bekas, gelas dan botol air mineral bekas, pot bekas ataupun wadah lain yang sudah tidak digunakan lagi. Seni decoupage ini adalah sebuah seni menempelkan berbagai bahan baik berupa kain, kertas maupun tisu decoupage ke berbagai media.

4. Monitoring hasil kegiatan dilaksanakan 1 bulan sesudahnya untuk mengevaluasi apakah pelatihan yang diberikan telah diterapkan oleh masyarakat setempat dan menganalisis kendala-kendala yang dijumpai selama pelaksanaan mandiri oleh masyarakat.

\section{Tahap monitoring dan evaluasi}

Ketercapaian sasaran kegiatan dapat dinilai melalui 2 tahap:

1. Jangka Pendek

Dalam jangka pendek dinilai dari pengetahuan dan keterampilan masyarakat target pada saat kegiatan pelatihan dilaksanakan, baik dalam bentuk diskusi tanya jawab pada saat sosialisasi tentang kompos maupun keterampilan masyarakat target dalam menyelesaikan seni decoupage berbasis pemanfaatan sampah rumah tangga.

2. Jangka Panjang

Ketercapaian sasaran kegiatan jangka panjang diukur dari laporan permasalahan sampah dari Dinas Kebersihan setempat maupun perkembangan kerajinan decoupage berbasis sampah rumah tangga di daerah setempat.

\section{HASIL DAN KETERCAPAIAN SASARAN}

Sosialiasi pemanfaat sampah rumah tangga menjadi barang bernilai ekonomis telah dilakukan di Kepenghuluan Pelita dan Kepenghuluan Sukamaju Kecamatan Bagan Sinembah Kabupaten Rokan Hilir. Kegiatan ini terlaksana dengan melibatkan mahasiswa kukerta UNRI di kedua kepenghuluan tersebut. Dalam 
pelaksanaan kegiatan, dibagi menjadi 2 tahap yaitu sosialisasi pembuatan kompos serta pengenalan tanaman obat di Kepenghuluan Sukamaju serta pelatihan seni decoupage di Kepenghuluan Pelita.

\section{Sosialiasi pembuatan kompos dan pengenalan tanaman berkhasiat obat}

Kegiatan ini dilaksanakan pada tanggal 30 Juli 2018 bertempat di Kepenghuluan Sukamaju. Target masyarakat pada kegiatan ini adalah ibu-ibu PKK dari Kepenghuluan Pelita dan Kepenghuluan Sukamaju sendiri. Kegiatan ini dihadir oleh 20 orang anggota PKK dari kedua kepenghuluan. Pada kegiatan ini dilakukan sosialisasi tentang sampah dan permasalahan yang dapat ditimbulkannya, cara pembuatan kompos dari sampah organik rumah tangga serta pengenalan tanaman berkhasiat obat. Sosialisasi dilakukan dalam bentuk presentasi materi diikuti dengan diskusi tanya jawab.

Dari diskusi yang dilakukan dapat diketahui bahwa masih sangat sedikit masyarakat yang paham bagaiman memilah dan mengelola sampah rumah tangga yang benar. Hampir seluruh peserta menyatakan tidak pernah memilah sampah organik dan organik yang dihasilkan. Rata-rata mereka menempatkan pada satu tempat sampah yang sama dan membuangnya ke tempat pembuangan sampah yang ada, ditimbun dalam tanah atau dibakar di pekarangan rumah masing-masing. Seluruh peserta yang hadir mengaku belum pernah mendapatkan pengetahuan tentang bagaimana mengolah sampah organik rumah tangga menjadi kompos. Beberapa peserta mengaku selama ini hanya menumpuk sampah organik yang berasal dari dedauan dalam suatu lubang di pekarangan dan membiarkan sampah terurai secara alami tanpa adanya perlakuan khusus. Hasil uraian sampah tersebut juga kadang diabaikan begitu saja. Beberapa orang peserta lainnya mengaku membakar sampah organik tersebut (yang kadang masih tercampur dengan bahan anorganik) dan hasil bakarannya dicampur dengan tanah dan dimanfaatkan sebagai media tanaman.

Dalam kegiatan ini, teknik pembuatan kompos yang disosialisasikan adalah pembuatan kompos dengan menggunakan starter EM4. Tim mengajarkan kepada peserta bagaimana teknik pembuatan kompos yang benar, media yang digunakan, tanda-tanda keberhasilan pembuatan kompos serta berbagai kendala yang sering dihadapi dalam pembuatan kompos. Pemisahan bahan organik sebagai sumber kompos dari bahan organik yang mengandung protein serta paparan minimal oleh sinar matahari menjadi penekanan khusus dalam menjaga keberhasilan pembuatan kompos tersebut. Pada kegiatan ini tim juga memberikan starter EM4 kepada kedua kelompok PKK untuk dapat mereka manfaatkan dalam memulai pembuatan kompos di desa masingmasing. Dalam pembuatan kompos tersebut, kedua tim PKK dibantu oleh mahasiswa Kukerta dari masingmasing kepenghuluan, terutama dalam menyiapkan komposer, sehingga dihasilkan komposer yang baik. Kompos cair yang dihasilkan selama proses pembuatan kompos telah mulai dimanfaat mahasiswa kukerta dan ibu-ibu PKK untuk memupuki tanaman berkhasiat obat yang dikelola oleh masing-masing PKK.

Selain itu, dalam melengkapi koleksi tanaman berkhasiat obat yang dikelola oleha masing-masing PKK, tim mengenalkan serta menghibahkan sebanyak 10 jenis tanaman berkhasiat obat yang mudah dikembangkan oleh masyarakat. Tanaman tersebut antara lain pegagan, sembung nyawa, keji beling, gendola, krema cina, umbi dewa, bawang dayak, lempeni, sambiloto dan binahong. Tanaman berkhasiat obat tersebut didapatkan dari petani herbal yang selama ini menjadi salah satu mitra lokasi pendidikan mahasiswa FK UNRI tentang etnomedicine dan tanaman berkhasiat obat.

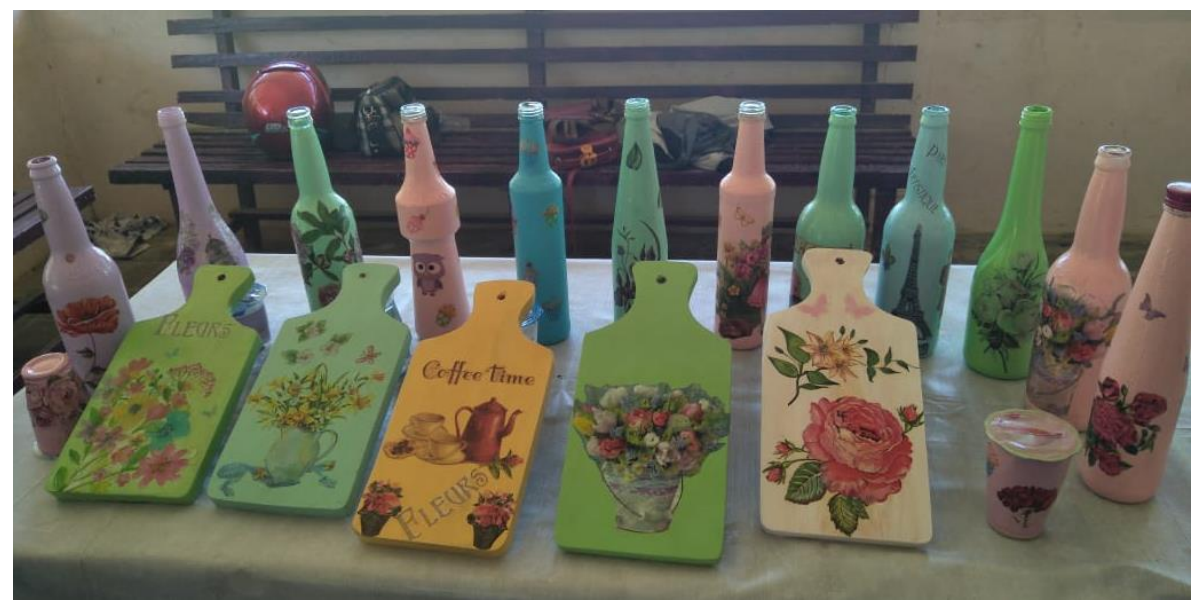

Gambar 1. Hasil karya peserta pelatihan seni decoupage 


\section{Pelatihan seni decoupage}

Pelatihan pembuatan karya seni dengan teknik decoupage dan memanfaatkan barang bekas di rumah tangga dilaksanakan pada tanggal 31 Juli 2018 dan 12 Agustus 2018. Peserta pelatihan ini adalah guru TK-PAUD dari Kepenghuluan Pelita dan Kepenghuluan Sukamaju serta ibu PKK dari Kepenghuluan Pelita. Pada pelatihan ini, peserta diajarkan teknik decoupage dengan menggunakan media licin seperti botol dan kaleng bekas maupun media kesat seperti permukaan kayu, tanah liat dan sebagainya. Setelah penjelasan singkat mengenai teknik dasar decoupage, peserta diminta untuk mempraktekkan langsung di kedua tipe media tersebut. Dengan demikian peserta dapat merasakan langsung bagaimana cara menghias barang bekas dengan teknik decoupage dan dapat mengetahui kesulitan serta cara mengatasi kesulitan tersebut secara langsung. Pada kegiatan pertama yang dilaksanakan di TK Kartini Kepenghuluan Pelita, tim sekaligus mengajarkan kepada mahasiswa kukerta Kepenghuluan Pelita dan Sukamaju bagaimana cara mengerjakan seni decoupage. Mahasiswa kukerta ini berikutnya mengajarkan kembali ke ibu-ibu PKK di kepenghuluan masing-masing seni decoupage tersebut sehingga secara kuantitas, jumlah masyarakat yang mengetahui pemanfaatan seni decoupage untuk mengubah barang bekas rumah tangga menjadi barang bernilai seni dan ekonomi semakin banyak. Selanjutnya guru TK dan anggota PKK tersebut diharapkan juga mengajarkan ke anggota masyarakat lain terutama ibu-ibu dan remaja putri.

Dalam kegiatan ini, antusiasme peserta sangat tinggi. Peserta mengerjakan secara mandiri seni decoupage pada media botol dan kaleng dari rumah masing-masing. Khusus untuk pengenalan pada media kesat seperti permukaan kayu, tim menyediakan media tersebut sebagai media latihan bagi peserta.

\section{KESIMPULAN}

Dari uraian di atas dapat disimpulkan bahwa peserta kegiatan masih banyak yang belum memahami pengelolaan sampah dengan benar dan belum memanfaatkan sampah rumah tangga baik organik maupun organik secara optimal. Melalui pelatihan ini, masyarakat target telah memiliki pengetahuan dan keterampilan bagaimana memanfaatkan sampah organik menjadi kompos dan bagaimana membuat botol, kaleng dan limbah anorganik lainnya di rumah tangga menjadi bahan bernilai ekonomi tinggi melalui kerajinan seni decoupage. Strategi pemasaran hasil pengolahan limbah rumah tangga ini perlu menjadi perhatian senlanjutnya, termasuk mengenali pangsa pasar dari hasil olahan sampah rumah tangga tersebut. Dengan demikian diharapkan keterampilan yang telah diperoleh masyarakat tersebut bisa menjadi salah satu sumber penghasilan rumah tangga.

\section{UCAPAN TERIMA KASIH}

Ucapan terima kasih disampaikan kepada pimpinan Universitas Riau atas dukungan moril dan materil sehingga kegiatan ini dapat terselenggara dengan baik. Kegiatan ini didanai oleh Hibah Pengabdian Kepada Masyarakat Universitas Riau tahun 2018.

\section{DAFTAR PUSTAKA}

Chandra, B. 2006. Pengantar kesehatan lingkungan. Jakarta: Penerbit Buku Kedokteran.

Damanhuri E, Padmi T. Pengelolaan Sampah. 2010. Fakultas teknik sipil dan lingkungan: Bandung

Dinas Kesehatan Kabupaten Rokan Hilir. 2016. Profil Kesehatan Kabupaten Rokan Hilir tahun 2015. Rokan Hilir Sri Indrapura: Dinkes Kabupaten Rokan Hilir

Faizah. 2008. Pengelolaan sampah berbasis masyarakat. Semarang: Universitas Diponegoro 